\title{
Honey bee lines selected for high propolis production also have superior hygienic behavior and increased honey and pollen stores
}

\author{
D. Nicodemo ${ }^{1,2}$, D. De Jong ${ }^{2}$, R.H.N. Couto ${ }^{3}$ and E.B. Malheiros ${ }^{4}$ \\ ${ }^{1}$ Curso de Zootecnia, Universidade Estadual Paulista, Dracena, SP, Brasil \\ ${ }^{2}$ Departamento de Genética, Faculdade de Medicina, \\ Universidade de São Paulo, Ribeirão Preto, SP, Brasil \\ ${ }^{3}$ Departamento de Zootecnia, Universidade Estadual Paulista, \\ Jaboticabal, SP, Brasil \\ ${ }^{4}$ Departamento de Ciências Exatas, Universidade Estadual Paulista, \\ Jaboticabal, SP, Brasil \\ Corresponding author: D. Nicodemo \\ E-mail: nicodemo@dracena.unesp.br
}

Genet. Mol. Res. 12 (4): 6931-6938 (2013)

Received November 1, 2013

Accepted December 16, 2013

Published December 19, 2013

DOI http://dx.doi.org/10.4238/2013.December.19.12

\begin{abstract}
Honey bees use propolis to defend against invaders and disease organisms. As some colonies produce much more propolis than others, we investigated whether propolis collecting is associated with disease resistance traits, including hygienic behavior and resistance to the parasitic bee mite, Varroa destructor. The three highest (HP) and three lowest propolis-producing (LP) colonies among 36 Africanized honey bee colonies were initially selected. Queens and drones from these colonies were crossed through artificial insemination to produce five colonies of each of the following crosses: $\mathrm{HP}+\mathrm{X} \mathrm{HP}^{\lambda}, \mathrm{LP}_{+} \propto \mathrm{X}$

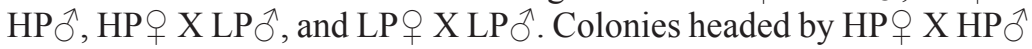
queens produced significantly more propolis than those with $\mathrm{HP}+\mathrm{X}$

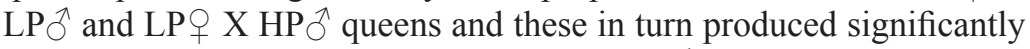
more propolis than those headed by $\mathrm{LP}+\mathrm{X} \operatorname{LP} \hat{\gamma}$ queens. The brood cell
\end{abstract}


uncapping rate of the high-propolis-producing colonies in the hygienic behavior test was significantly superior to that of the other groups. The LP X LP group was significantly less hygienic than the two HP X LP crosses, based on the evaluation of the rate of removal of pin-killed pupae. The HP X HP colonies were significantly more hygienic than the other crosses. No significant differences were found in mite infestation rates among the groups of colonies; although overall, colony infestation rates were quite low (1.0 to 3.2 mites per 100 brood cells), which could have masked such effects. Honey and pollen stores were significantly and positively correlated with propolis production.

Key words: Controlled mating; Propolis production; Cleaning behavior; Varroa destructor

\section{INTRODUCTION}

Hygienic behavior, first described in honey bee colonies tolerant to American foulbrood disease (Rothenbuhler and Thompson, 1956), has also been indicated as important for the control of other brood diseases, such as chalkbrood and Varroosis (Spivak, 1996). Along with this behavioral response to brood diseases, honey bees also use propolis to control disease organisms (Kamel et al., 2013) and even to seal off enemies such as vertebrate predators and small hive beetles that they encounter in the colony (Couto and Couto, 2006).

Hygienic behavior begins with the detection of sick or dead brood, subsequent uncapping of the brood cell and removal of the larva or pupa (Rothenbuhler, 1964; Wilson-Rich et al., 2009). The expression of this characteristic in bees has been widely studied and it is estimated that up to 30 pairs of genes are involved in this process (Moritz, 1988; Kefuss et al., 1996; Gramacho et al., 1999). Environmental factors, such as nectar flow (Momot and Rothenbuhler, 1971; Spivak, 1996; Boecking and Spivak, 1999) and relative humidity of the air and age of the combs (Couto and Couto, 2006) also affect the efficiency of hygienic behavior by honey bees.

Propolis is a product elaborated by bees from plant resins; it is used to fill holes and cracks, reduce hive entrances, combat bacteria and fungi, and mummify small dead invaders that the bees cannot remove from the hive (Marcucci, 1996; Park et al., 2002). Besides these utilities, propolis promotes social immunity in the colony, by reducing the dissemination of disease organisms in these social insects (Schmid-Hempel, 1998; Farnesi et al., 2009; Simone et al., 2009; Simone-Finstrom and Spivak, 2012; Roode et al., 2013).

Considering that individually, honey bees have a less efficient immune system compared to non-social insects (Evans et al., 2006), these benefits of propolis could be part of a group of behavioral mechanisms and other characteristics that social bees have developed to collectively resist diseases and pests (Evans and Spivak, 2010; Simone-Finstrom and Spivak, 2010). When we consider the advantages for the colony of propolis in the hive and the possibility of economic gain from selling this product, it is clear that selection for propolis production is desirable and viable, especially given the high degree of heritability $\left(\mathrm{h}^{2}=0.87\right)$ for this characteristic (Garcia et al., 2013). Hygienic behavior also has a high heritability rate, ranging from 0.52 to 0.65 (Rinderer, 1986; Harbo and Harris, 1999; Garcia et al., 2013). However, Garcia et al. (2013) found no significant correlation between propolis production and hygienic 
behavior, which would make indirect selection for one of the characteristics by selecting for the other unviable.

Considering that propolis is important for colony health due to its antimicrobial properties (Ghisalberti, 1979; Machado et al., 1991; Marcucci, 1995; Bastos et al., 2008), we examined the relationship between propolis production tendencies, hygienic behavior and susceptibility to the parasitic bee mite, Varroa destructor.

\section{MATERIAL AND METHODS}

Thirty-six Africanized honey bee colonies were evaluated for propolis production. These were wild-type Africanized colonies, maintained in Jaboticabal, São Paulo State, $21^{\circ} 15^{\prime} 22^{\prime \prime}$ latitude south and $48^{\circ} 18^{\prime} 68^{\prime \prime}$ longitude west, at 595 meters altitude. The climate in this area is subtropical, with a hot rainy summer and a relatively dry and cooler winter. The three colonies that were most productive (HP) and the three least productive (LP) were selected as parental colonies. Five colonies were produced of each of the following crosses: HP $q$ X

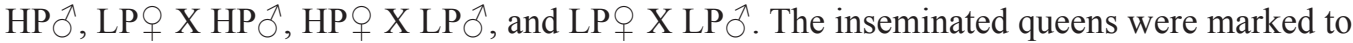
facilitate identification. After 60 days, when all of the worker bees had been replaced, data collection was initiated. See Nicodemo et al. (2013) for details of the selection process, propolis production apparatus and production data.

Hygienic behavior was evaluated in the progeny colonies using the pin-killing method (Gramacho et al., 1999). One hundred sealed worker brood cells of a comb from each colony were perforated with a needle to kill the pupae. Every $12 \mathrm{~h}$, for three days, the number of uncapped cells and the number of pupae that were completely removed were counted.

The number of mites ( $V$. destructor) in brood cells containing worker pupae was evaluated in $50 \mathrm{comb}$ cells on each side of a brood comb in each progeny colony. An otoscope and a fiberlight were used to help locate and identify the mites and progeny. The mites were separated into age categories, including original adult females, young adult female progeny, female deutonymphs, protonymphs (males were hard to distinguish from protonymphs and were lumped together with the protonymph counts), and eggs (Piccirillo and De Jong, 2003). The pupae that were selected had dark eyes and a light-colored body, and were considered to be approximately 17 days old (Nunes-Silva et al., 2006).

Mite infestations on adult bees were determined by collecting approximately 200 bees brushed from brood combs of each colony into a $70 \%$ ethanol/water solution, agitating the collection jars mechanically for $1 \mathrm{~h}$ and straining the mites through a metal screen (De Jong et al., 1982). The number of mites was divided by the number of the bees in the sample.

The colony conditions were evaluated by mapping the comb areas of worker brood (eggs, larvae and pupae) and food stores (honey and pollen). The combs of each F1 colony were taken to the laboratory and placed in a frame holder with $2 \times 2 \mathrm{~cm}$ wire grid to measure the area covered by brood and food (Al-Tikrity et al., 1971).

Comparisons between the different groups of F1 colonies were made using analysis of variance, in a completely randomized experimental design, with five repetitions, for propolis production, brood infestation by $V$. destructor and brood and food area in the comb. Hygienic behavior was analyzed in a completely randomized experimental design, with each group subdivided in time, with five repetitions. Pearson's correlation was used to determine if propolis production per hive correlated with the brood, honey and pollen store comb areas. 
Comparisons of means were made using the Tukey test, and the data were processed with the SAS program (SAS Institute, 1993).

\section{RESULTS}

The HP $\odot$ X HP $\bigcirc$ colonies were more efficient at uncapping killed brood than all the other types of colonies, uncapping $46 \%$ of the perforated cells in the first $12 \mathrm{~h}$, and $76 \%$ after $24 \mathrm{~h}$ (Figure 1). After $72 \mathrm{~h}$, these high level propolis producing colonies had the highest rate of uncapped cells (97\%). The LP $\odot$ X LP $\bigcirc$ colonies had a lower rate of cell uncapping than the mixed cross bees, although the differences were not significant $(\mathrm{P}>0.20)$.

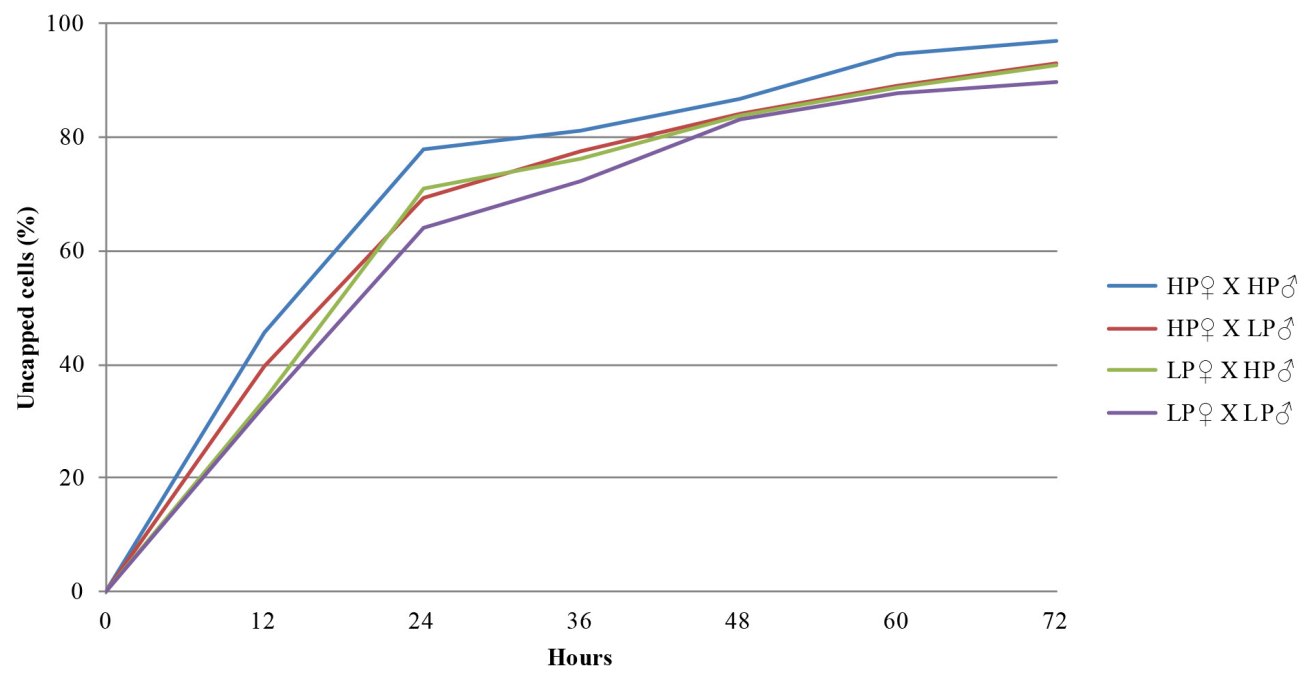

Figure 1. Percentage of pin killed brood cells that were uncapped, counted for three days at intervals of $12 \mathrm{~h}$, in

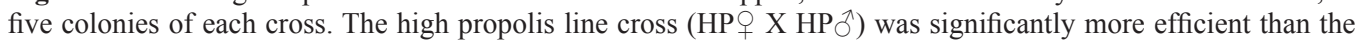
hybrid crosses (high line $\mathrm{X}$ low line); these in turn were significantly more efficient than the low propolis line cross $\left(\mathrm{LP}_{+} \mathrm{X} \mathrm{LP}{ }^{\Uparrow}\right)$.

The superior hygienic behavior in colonies headed by HP X HP queens was again demonstrated when an evaluation of the number of pupae removed from the brood cells was made (Figure 2). The HP $q$ X HP ${ }^{\lambda}$ bees removed 38 and $68 \%$ of the pupae 12 and $24 \mathrm{~h}$ after perforation, respectively. After $72 \mathrm{~h}, 96 \%$ of the pupae had been removed. In this evaluation, the colonies with bees produced from reciprocal crosses were similar to each other and significantly superior to colonies with low propolis producing bees. The performance of the HP $q \mathrm{X}$ $\mathrm{HP} \widehat{\jmath}$ group was $28 \%$ superior to the LP + X LP $\widehat{\partial}$ colonies $24 \mathrm{~h}$ after the brood was perforated; this was period when the differences between groups were greatest.

The infestation rate with Varroa on adult bees was higher in the HP X HP colonies, lower in the LP X LP colonies, and intermediate in the crosses between HP and LP, although the differences were not significant, possibly because overall, the infestation rates were low (Table 1). There were no significant differences in the Varroa progeny frequencies between the different categories of propolis producing colonies. 


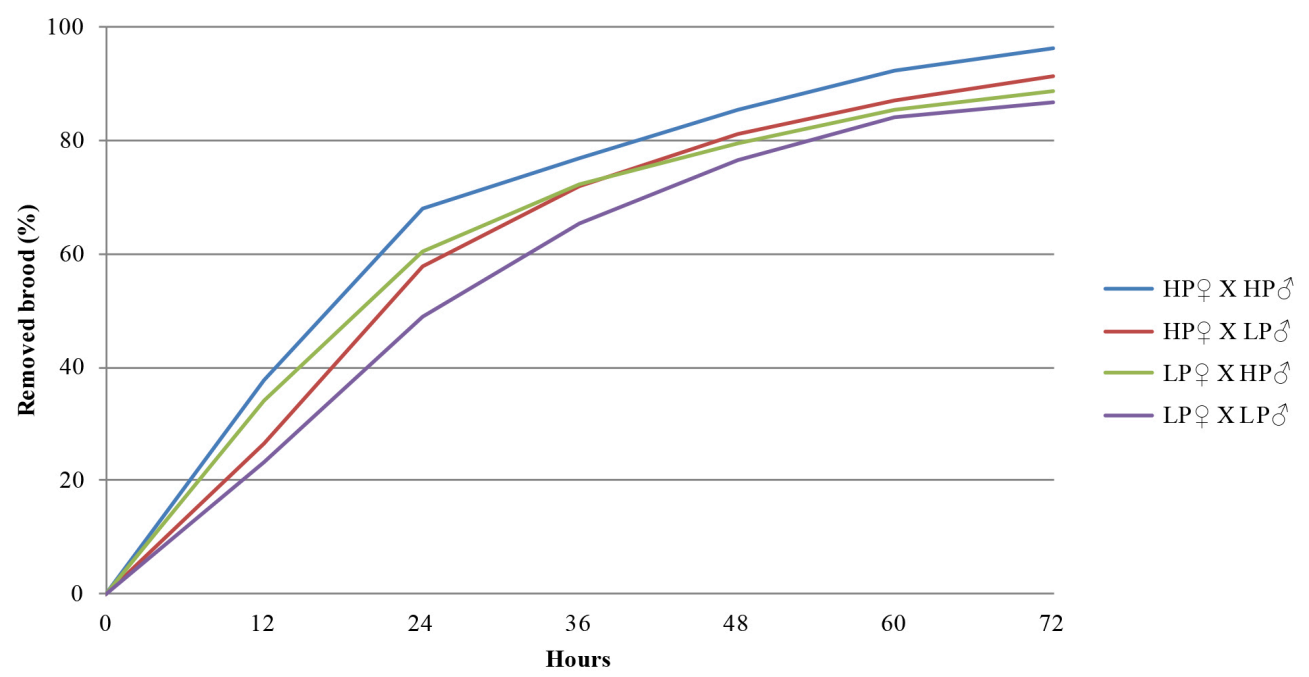

Figure 2. Percentage of pin-killed brood cells from which the pupae were completely removed, counted for three days at intervals of $12 \mathrm{~h}$, in five colonies of each cross. The high propolis line cross ( $\mathrm{HP} q \mathrm{X} \mathrm{HP} \delta$ ) was significantly more efficient than the hybrid crosses (high line X low line); these in turn were significantly more efficient than the low propolis line cross (LPㅇ X LP $\left.{ }^{\Uparrow}\right)$.

Table 1. Means \pm standard deviation of the number of mites of different stages per 100 worker brood cells, in colonies descendants of colonies selected for high (HP) and low production of propolis (LP).

\begin{tabular}{|c|c|c|c|c|c|c|}
\hline \multirow[t]{2}{*}{ Groups } & \multicolumn{5}{|c|}{ Mites in worker brood cells } & \multirow[t]{2}{*}{ Adult bees } \\
\hline & Egg & Protonymph & Deutonymph & New 9 & 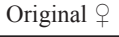 & \\
\hline$\overline{\mathrm{HP}}+\mathrm{X} \mathrm{HP}$ & $0.0 \pm 0.0$ & $0.2 \pm 0.5$ & $0.6 \pm 0.6$ & $2.0 \pm 1.6$ & $2.8 \pm 2.5$ & $3.5 \pm 2.5$ \\
\hline $\mathrm{HP}+\mathrm{X} \operatorname{LP} \hat{0}$ & $0.8 \pm 1.8$ & $1.2 \pm 2.7$ & $0.6 \pm 0.6$ & $2.8 \pm 4.1$ & $3.2 \pm 3.8$ & $2.9 \pm 1.9$ \\
\hline $\mathrm{LP}+\mathrm{X} \mathrm{HP}$ & $0.2 \pm 0.5$ & $0.4 \pm 0.6$ & $0.4 \pm 0.6$ & $1.6 \pm 0.9$ & $2.8 \pm 1.3$ & $2.5 \pm 1.5$ \\
\hline $\mathrm{LP}_{+} \mathrm{X} \mathrm{LP}^{\wedge}$ & $0.0 \pm 0.0$ & $0.0 \pm 0.0$ & $0.4 \pm 0.6$ & $0.2 \pm 0.5$ & $1.0 \pm 1.2$ & $1.9 \pm 1.2$ \\
\hline
\end{tabular}

There were no significant differences in brood area among the different categories of propolis production colonies (Table 2). When brood area was divided into components (eggs, larvae, pupae), the differences were also not significant; there was also no significant correlation with tendency to produce propolis.

Table 2. Means \pm standard deviation of the area $\left(\mathrm{cm}^{2}\right)$, in each comb, containing worker bee, eggs, larvae, and pupae in colonies that were descendants of colonies selected for high (HP) and low production of propolis (LP), Pearson's correlation coefficient (r) and P value.

\begin{tabular}{|c|c|c|c|c|c|}
\hline \multirow[t]{2}{*}{ Statistics } & & \multicolumn{4}{|c|}{ Brood areas $\left(\mathrm{cm}^{2}\right)$} \\
\hline & & Eggs & Larvae & Pupae & Total \\
\hline \multirow{4}{*}{ Means $\pm \mathrm{SD}$} & $\mathrm{HP} Q \mathrm{X} \mathrm{HP}$ & $54 \pm 29$ & $118 \pm 49$ & $207 \pm 73.39$ & $379 \pm 150$ \\
\hline & $\mathrm{HP}+\mathrm{X} \operatorname{LP} \hat{\jmath}$ & $47 \pm 27$ & $173 \pm 27$ & $292 \pm 46.79$ & $512 \pm 102$ \\
\hline & LPQ X HP & $79 \pm 37$ & $174 \pm 37$ & $291 \pm 34.21$ & $544 \pm 84$ \\
\hline & $\mathrm{LP}+\mathrm{X} \mathrm{LP} \hat{\jmath}$ & $45 \pm 34$ & $124 \pm 34$ & $275 \pm 82.00$ & $444 \pm 128$ \\
\hline $\mathrm{r}$ & & 0.36 & 0.12 & -0.04 & 0.09 \\
\hline$P$ value & & 0.12 & 0.60 & 0.86 & $>0.20$ \\
\hline
\end{tabular}


Honey production was significantly correlated with propolis production. The HP 9 X HP $\bigcirc$ colonies had $49 \%$ more honey in the comb than the LP $\odot$ X LP $\bigcirc$ colonies (Table 3). Pollen in the comb was also significantly correlated with propolis production. The high line propolis production colonies had $22 \%$ more pollen in the comb than the low-line propolis producing colonies.

Table 3. Means \pm standard deviation of the area $\left(\mathrm{cm}^{2}\right)$ in each comb, of honey and pollen, in each group of five propolis-producing hives. Propolis production $(\mathrm{g})$ is given as a mean for each type of colony.

\begin{tabular}{|c|c|c|c|}
\hline Type of colony & Honey & Pollen & Propolis production \\
\hline$\overline{\mathrm{HP}} \bigcirc \mathrm{X} \mathrm{HP} \hat{\mathrm{O}}$ & $466 \pm 85$ & $121 \pm 13$ & $22.4 \pm 13.0$ \\
\hline $\mathrm{HP}+\mathrm{X} \mathrm{LP}^{\hat{1}}$ & $316 \pm 146$ & $111 \pm 27$ & $4.3 \pm 2.5$ \\
\hline $\mathrm{LP}+\mathrm{X} \mathrm{HP}^{\hat{O}}$ & $377 \pm 44$ & $106 \pm 19$ & $4.0 \pm 5.2$ \\
\hline $\mathrm{LP}+\mathrm{XLP}^{\pi}$ & $313 \pm 30$ & $99 \pm 31$ & $0.65 \pm 0.92$ \\
\hline $\mathrm{r}$ & 0.77 & 0.50 & \\
\hline P value & $<0.01$ & 0.03 & \\
\hline
\end{tabular}

Pearson's correlations (r) were calculated for food stores as a function of individual colony propolis production.

\section{DISCUSSION}

Gonçalves and Kerr (1970) reported that colonies that are resistant to diseases remove at least $50 \%$ of the killed brood within $48 \mathrm{~h}$, completing removal within $72 \mathrm{~h}$. In our experiment, all of the types of bees removed more than $50 \%$ of the pin-killed pupae within $48 \mathrm{~h}$; however, after $72 \mathrm{~h}, 3.6,8.8,11.2$, and $13.4 \%$ of the dead pupae had not been removed, in

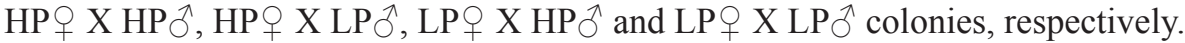

Directed selection for propolis production promoted increased hygienic behavior in the colonies. This tendency was not found by Garcia et al. (2013), who only tested colonies selected for high propolis production. In our study, we also included and compared colonies selected for low propolis production, which allowed us to differentiate the degree of hygienic behavior as a function of propolis production tendencies. Using Bayesian inference, Padilha et al. (2013) found a positive correlation between propolis production and hygienic behavior $(\mathrm{r}=$ $0.15)$; the high positive residual correlation $(r=0.65)$ leads them to conclude that environment has a strong effect on these characteristics.

The rate of brood cell infestation by $V$. destructor was similar among the colony groups; the mean infestation rate varied from 1.0 to $2.6 \%$. It is known that infestation by this mite is influenced by the type of bee and by local climate conditions (De Jong et al., 1984; Moretto et al., 1991; De Jong and Soares, 1997). Infestation rates are higher in temperate climates, making it necessary to apply acaricides or other treatments in order to maintain the colonies alive (De Jong et al., 1984). Among the different types of honey bees, Africanized bees are more tolerant to Varroa than are the European races (Moretto and Mello, 1999; Martin and Medina, 2004). The local tropical climate and the fact that these are Africanized bees contributed to the low rates of infestation with $V$. destructor.

Although infestation with the Varroa mite is known to negatively affect colony production (De Jong et al., 1984), a tendency for a higher rate of infestation with this mite in colonies selected for propolis production was also found by Padilha et al. (2013), who reported a correlation of 0.49 between these two characteristics. However, bees selected for hygienic behavior have been found to be less susceptible to diseases and mite pests (Spivak and Reuter, 1998). 
Generally speaking, we found that the colonies selected for HP also produced more honey and pollen than those selected for LP, suggesting a relationship between these characteristics. Manrique and Soares (2002) also found that selection for honey production resulted in increased propolis production, and vice-versa.

\section{CONCLUSIONS}

Colonies that were descendants of a cross between superior propolis producers were significantly more hygienic than those from crosses between low propolis-producing colonies. Crosses between high and low propolis-producing colonies had intermediate hygienic capabilities, with no significant differences between reciprocal crosses. Varroa infestations were quite low and no significant correlations were found with propolis production or hygienic behavior in these Africanized honey bee colonies. Honey and pollen reserves were significantly more abundant in the high propolis producing colonies.

\section{ACKNOWLEDGMENTS}

Research supported by FAPESP, CNPq and FAEPA.

\section{REFERENCES}

Al-Tikrity WS, Hillmann RC, Benton AW and Clarke WW (1971). A new instrument for brood measurement in a honeybee colony. Am. Bee J. 111: 20-26.

Bastos EM, Simone M, Jorge DM, Soares AE, et al. (2008). In vitro study of the antimicrobial activity of Brazilian propolis against Paenibacillus larvae. J. Invertebr. Pathol. 97: 273-281.

Boecking O and Spivak M (1999). Behavioral defenses of honey bees against Varroa jacobsoni Oud. Apidologie 30: 141-158.

Couto RHN and Couto LA (2006). Apicultura: Manejo e Produtos. Funep, Jaboticabal.

De Jong D and Soares AEE (1997). An isolated population of Italian bees that has survived Varroa jacobsoni infestation without treatment for over 12 years. Am. Bee J. 137: 742-745.

De Jong D, Roma DA and Gonçalves LS (1982). A comparative analysis of shaking solutions for the detection of Varroa jacobsoni on adult honeybees. Apidologie 13: 297-306.

De Jong D, Gonçalves LS and Morse RA (1984). Dependence of climate on the virulence of Varroa jacobsoni. Bee World 65: 117-121.

Evans JD and Spivak M (2010). Socialized medicine: individual and communal disease barriers in honey bees. J. Invertebr. Pathol. 103 (Suppl 1): S62-S72.

Evans JD, Aronstein K, Chen YP, Hetru C, et al. (2006). Immune pathways and defence mechanisms in honey bees Apis mellifera. Insect Mol. Biol. 15: 645-656.

Farnesi AP, Aquino-Ferreira R, De Jong D, Bastos JK, et al. (2009). Effects of stingless bee and honey bee propolis on four species of bacteria. Genet. Mol. Res. 8: 635-640.

Garcia CR, Oliveira NTE, Camargo SC, Pires BG, et al. (2013). Honey and propolis production, hygiene and defense behaviors of two generations of Africanized honey bees. Sci. Agric. 70: 74-81.

Ghisalberti EL (1979). Propolis: A review. Bee World 60: 59-84.

Gonçalves LS and Kerr WE (1970). Genética, Seleção e Melhoramento. 1. Noções sobre Genética e Melhoramento em Abelhas. In: I Congresso Brasileiro de Apicultura, Florianópolis, Anais, 8-36.

Gramacho KP, Gonçalves LS, Rosenkranz P and De Jong D (1999). Influence of body fluid from pin-killed honey bee pupae on hygienic behavior. Apidologie 30: 367-374.

Harbo JR and Harris JW (1999). Selecting honey bees for resistance to Varroa jacobsoni. Apidologie 30: 183-196.

Kamel AA, Moustafa AA and Nafea EA (2013). Propolis as a natural antibiotic to control American foulbrood disease in honey bee colonies. Afr. J. Agric. Res. 8: 3047-3062.

Kefuss J, Taber S, Vanpoucke J and Reye F (1996). A practical method to test for disease resistance in honey bees. Am. 
Bee J. 136: 31-32.

Machado JM, Martinez AS and Torres E (1991). Accion del propóleos contra alguns virus de los animales domesticos. Rev. Cub. Cienc. Vet. 22: 25-30.

Manrique AJ and Soares AEE (2002). Start of africanized honey bee selection program for increased propolis production and its effect on honey production. Interciencia 27:312-316.

Marcucci MC (1995). Propolis: chemical composition, biological properties and therapeutic activity. Apidologie 26: 83-99.

Marcucci MC (1996). Propriedades biológicas e terapêuticas dos constituintes químicos da própolis. Quim. Nova 19: 529-535.

Martin SJ and Medina LM (2004). Africanized honeybees have unique tolerance to Varroa mites. Trends Parasitol. 20: $112-114$

Momot JP and Rothenbuhler WC (1971). Behaviour genetics of nest cleaning in honeybees. VI. Interactions of age and genotype of bees, and nectar flow. J. Apic. Res. 10: 11-21.

Moretto G and Mello LJ (1999). Varroa jacobsoni infestation of adult Africanized and Italian honey bees (Apis mellifera) in mixed colonies in Brazil. Genet. Mol. Biol. 22: 321-323.

Moretto G, Gonçalves LS, De Jong D and Bichuette MZ (1991). The effects of climate and bee race on Varroa jacobsoni Oud. infestations in Brazil. Apidologie 22: 197-203.

Moritz RFA (1988). A reevaluation of the two-locus model for hygienic behaviour in honeybees (Apis mellifera L.). J. Hered. 79: 257-262.

Nicodemo D, Malheiros EB, De Jong D and Couto RHN (2013). Increased brood viability and longer lifespan of honeybees selected for propolis production. Apidologie Doi: 10. 1007/s13592-013-0249-y.

Nunes-Silva P, Gonçalves LS, Francoy TM and De Jong D (2006). Rate of growth and development time of Africanized honey bee (Apis mellifera) queens and workers during ontogenetic development. Braz. J. Morphol. Sci. 23: 325-332.

Padilha AH, Sattler A, Cobuci JA and McManus CM (2013). Genetic parameters for five traits in Africanized honeybees using Bayesian inference. Genet. Mol. Biol. 36: 207-213.

Park YK, Alencar SM and Aguiar CL (2002). Botanical origin and chemical composition of Brazilian propolis. J. Agric. Food Chem. 50: 2502-2506.

Piccirillo GA and De Jong D (2003). The influence of brood comb cell size on the reproductive behavior of the ectoparasitic mite Varroa destructor in Africanized honey bee colonies. Genet. Mol. Res. 2: 36-42.

Rinderer TE (1986). Bee Genetics and Breeding. Academic Press, Orlando.

Roode JC, Lefèvre T and Hunter MD (2013). Self-Medication in animals. Science 340: 150-151.

Rothenbuhler WC (1964). Behaviour genetics of nest cleaning in honey bees. IV. Responses of $F_{1}$ and backcross generations to disease-killed brood. Am. Zool. 4: 111-123.

Rothenbuhler WC and Thompson VC (1956). Resistance to American foulbrood in honey bees. I. Differential survival of larvae of different genetic lines. J. Econ. Entomol. 49: 470-475.

SAS Institute - Statistical Analysis Systems (1993). User's Guide: Stat. Version 6, 12. 4th edn. Cary.

Schmid-Hempel P (1998). Parasites in Social Insects. Princeton University Press, Princeton.

Simone-Finstrom MD and Spivak M (2010). Propolis and bee health: the natural history and significance of resin use by honey bees. Apidologie 41: 295-311.

Simone-Finstrom MD and Spivak M (2012). Increased resin collection after parasite challenge: a case of self-medication in honey bees? PLoS One 7: e34601.

Simone M, Evans JD and Spivak M (2009). Resin collection and social immunity in honey bees. Evolution 63: 3016-3022. Spivak M (1996). Honey bee hygienic behaviour and defense against Varroa jacobsoni. Apidologie 27: 245-260.

Spivak M and Reuter GS (1998). Performance of hygienic honey bee colonies in a commercial apiary. Apidologie 29: 291-302.

Wilson-Rich N, Spivak M, Fefferman NH and Starks PT (2009). Genetic, individual, and group facilitation of disease resistance in insect societies. Anпи. Rev. Entomol. 54: 405-423. 